Era Hukum - Jurnal Imiah Ilmu Hukum is licensed under Creative Commons Attribution 4. O Internatio nal License, which allows otherwriters to use, distribute, ond/or build upon this article, as long as the original work is properity cited.

\title{
PENERAPAN PRINSIP FIRST COME FIRST SERVED DALAM \\ PENYELESAIAN TUMPANG TINDIH WILAYAH IZIN USAHA PERTAMBANGAN
}

\author{
Ahmad Redi \\ (Dosen Fakultas Hukum Universitas Tarumanagara. Meraih Sarjana Hukum pada Fakultas \\ Hukum Universitas Diponegori, Magister Hukum pada Fakultas Hukum Universitas Indonesia, \\ Doktor (Dr.) pada Fakultas Hukum Universitas Indonesia) \\ (E-mail: ahmadr@fh.untar.ac.id) \\ Susanto Dharma \\ (Mahasiswa Program S1 Fakultas Hukum Universitas Tarumanagara)
}

Received: 20 Agustus 2019; Accepted: 03 September 2019; Published: 29 Oktober 2019

\begin{abstract}
Indonesian mining industry have undergone impressive pace of development that dispute concerning overlapping on Mining Business License Area which triggers Mining Business License cancellation or revocation. One of such incidents occur between PT Kemakmuran Pertiwi Tambang and PT Wana Kencana Mineral, whereas both companies obtained Mining Business License for the same commodity on the same Mining Business License Area. How can legal certainty be relied upon concerning the Operation Production Mining Business License for holders of Exploration Mining Business License on the overlapped Mining Business License Area based on Mining Law and does the revocation conducted by the Governor of North Maluku has been in accordance with the applicable regulation? To answer both issues above, the author utilized normative qualitative analysis technique and interviews as supporting data. Based on Law No. 4 Th. 2009 concerning mineral and coal mining Article 46, every holder of Exploration Mining Business License shall reserve the right to obtain Operation Production Mining Business License and by using "first come first served" system, PT Kemakmuran Pertiwi Tambang should have the first right to obtain Mining Business License since they have obtained the Exploration Mining Business License in 2005. Meanwhile the revocation conducted by the Governor of North Maluku is clearly against the applicable regulations such as Law No. 30 Th. 2014 concerning Government Administration, Law No. 9 Th. 2015 concerning Regional Regulation, General Principles of Good Governance and Article 119 of Mining Law concerning the terms for Mining Business License revocation.
\end{abstract}

Keywords: Mining Business, License, General Principles of Good Governance, Mining

\section{PENDAHULUAN}

\section{A. Latar Belakang}

Indonesia kaya akan sumber daya alam, namun penurunan produksi dan meningkatnya konsumsi domestik telah membuat Indonesia menjadi negara importir. Walaupun demikian, industri pertambangan negara Indonesia mengalami kemajuan. Indonesia bahkan mensuplai 20\% (dua puluh 
persen) dari timah dunia dan memiliki persediaan tembaga, nikel, emas, dan batubara yang cukup. Selain itu, ekspor minyak bumi dan mineral pada tahun 2011 bahkan mencapai angka 42\% (empat puluh dua persen). ${ }^{1)}$

Kekayaan tersebut juga berpotensi besar untuk menunjang kebutuhan hidup manusia, sehingga negara harus bijak dalam melakukan penguasaan dan pengusahaannya. Eksistensi sumber daya alam memiliki manfaat optimal bagi kesejahteraan dan kemakmuran sebuah negara. ${ }^{2)}$ Sebagai negara hukum yang merdeka dan berdaulat, Indonesia perlu memiliki aturan yang tegas dan jelas mengenai pengaturan sumber daya alam yang sejalan dengan Undang-Undang Dasar Negara Republik Indonesia (selanjutnya di sebut UUD 1945. ${ }^{3)}$

Peraturan mengenai pertambangan sangat menjadi perhatian khusus karena diatur dalam Pasal 33 UUD 1945 yang isinya secara garis besar menyatakan "negara menguasai

\footnotetext{
1 ) Anonim, "Indonesia Overview", www.resourcegovernance.org, diakses tanggal 28 Januari 2019, 17.50 WIB.

2 ) Ahmad Redi, Hukum Pertambangan (Jakarta: Gramata Publishing, 2014), 18.

3 ) Abrar. Saleng, Hukum Pertambangan (Yogyakarta: UII Press, 2004), 1.
}

cabang-cabang produksi seperti bumi, air dan kekayaan alam yang penting serta yang menguasai hajat hidup orang, dan penguasaan ini bertujuan untuk kemakmuran rakyat."

Penguasaan ini kemudian diatur dalam Undang-Undang Nomor 5 Tahun 1960 tentang Peraturan Dasar Pokok-Pokok Agraria (Lembaran Negara 1960-104, selanjutnya disebut UUPA), ${ }^{4)}$ beserta peraturan pelaksanaan lainnya. Hal ini bertujuan untuk mengatur dan memperkokoh Hak Menguasai Negara (selanjutnya disebut HMN). Untuk menghindari konflik di bidang sumber daya alam, maka diperlukan undangundang yang bersemangat pada Pasal 33 UUD 1945. Konstitusi tidak menjelaskan pengertian penguasaan negara secara tegas, sehingga peran dan pandangan Mahkamah Konstitusi (selanjut di sebut MK), menjadi sangat diperlukan untuk menafsirkan HMN terhadap relasi negara, rakyat, dan korporasi pada penguasaan tanah dan sumber daya alam di Indonesia.

Kekayaan alam berupa mineral dan batubara tidak dapat terbarukan. Keduanya mempunyai peranan penting

\footnotetext{
4) Muhamad Yamin dan Abdul Rahim Lubis, Hukum Pendaftaran Tanah (Bandung: Mandar Maju, 2008), 19.
} 
dalam memenuhi hajat hidup masyarakat di wilayah Indonesia. Oleh karena itu, dalam pengelolaannya negara harus menguasai usaha pertambangan sehingga dapat mencapai keadilan bagi kemakmuran dan kesejahteraan rakyat, serta memberi nilai tambah bagi perekonomian nasional.

Undang-Undang Nomor 4 Tahun 2009 tentang Pertambangan Mineral dan Batubara (selanjutnya disebut UndangUndang Pertambangan) Pasal 90 secara khusus mengatur pemberian hak berupa izin usaha pertambangan (selanjutnya disebut IUP) dan izin usaha pertambangan khusus (selanjutnya disebut IUPK). Kedua izin ini memberikan hak kepada pemegang izin untuk melakukan kegiatan eksplorasi maupun kegiatan operasi produksi, termasuk dapat memanfaatkan prasarana dan sarana umum untuk keperluan pertambangan baik sebagian atau seluruh tahapan usaha pertambangan setelah pemegang izin memenuhi ketentuan peraturan perundang-undangan.

Setiap Pemegang IUP Eksplorasi dan IUPK Eksplorasi mendapat jaminan pemberian IUP Operasi Produksi sebagaimana diatur dalam ketentuan Pasal 46 Ayat (1) Undang-Undang Pertambangan. IUP Operasi Produksi merupakan kelanjutan kegiatan usaha pertambangan.

Namun dalam prakteknya, terdapat penyimpangan Pasal 46 Ayat (1) Undang-Undang Pertambangan yaitu terdapat pembatalan yang dilakukan oleh gubernur terhadap IUP Operasi Produksi yang telah diterbitkan oleh Bupati. Kronologis kasus yang terjadi yaitu pada 27 April 2005, Bupati memberikan IUP Ekplorasi kepada PT Kemakmuran Pertiwi Tambang (selanjutnya disebut PT KPT). Kemudian pada 29 Oktober 2007 IUP ditingkatkan menjadi IUP Ekploitasi kepada PT Kemakmuran Pertiwi Tambang. Ternyata pada areal wilayah yang sama, Gubernur menerbitkan IUP Ekplorasi kepada PT Wana Kencana Mineral (selanjutnya disebut PT WKN) pada 27 Juni 2007. Kemudian pada tahun 2007 PT Kemakmuran Pertiwi Tambang menggugat Gubernur karena memberikan izin kepada PT Wana Kencana Mineral. Namun gugatan PTUN tersebut kalah pada tingkat peradilan PTUN, menang pada tingkat PTTUN, kalah pada tingkat Mahkamah 
Agung, dan juga kalah pada tingkat Peninjauan Kembali di Mahkamah Agung, dengan Nomor Putusan 90/PK/TUN/2009 tanggal 28

September 2009. Dalam putusan PK tersebut hanya mengadili dengan bunyi Menolak permohonan Peninjauan Kembali dari Para Pemohonan Peninjauan Kembali yaitu PT Kemakmuran Inti Utama Tambang dan PT Kemakmuran Pertiwi Tambang, serta menghukum Para Pemohon Peninjauan Kembali untuk membayar biaya perkara dalam Peninjauan Kembali ini ditetapkan sebanyak Rp 2.500.000,00 (dua juta lima ratus ribu rupiah).

Berdasarkan isi Putusan Peninjauan Kembali tersebut jelas bahwa tidak terjadi pemeriksaan substansial pada materi perkara. Putusan itu menyatakan bahwa izin yang diterbitkan Gubernur kepada PT Wana Kencana Mineral tetap sah, dan Mahkamah Agung tidak memerintahan untuk mencabut IUP milik PT Kemakmuran Inti Utama Tambang dan PT Kemakmuran Pertiwi Tambang.

PT Wana Kencana Sejati mengajukan gugatan tata usaha negara terhadap Bupati atas pemberian izin kepada PT
Kemakmuran Pertiwi Tambang dan PT Kemakmuran Inti Utama Tambang. Gugatan tersebut dimenangkan oleh PT Wahana Kencana Sejati pada tingkat PTUN. Namun pada tingkat PTTUN, Mahkamah Agung, dan Peninjauan Kembali di Mahkamah Agung, gugatan dimenangkan oleh Bupati dan PT Kemakmuran Pertiwi Tambang dengan Nomor Putusan 63/PK/TUN/2010 tanggal 4 Agustus 2010. Isi dari Putusan Peninjauan Kembali tersebut adalah menolak permohoan Peninjauan Kembali dari Pemohon Peninjauan Kembali yaitu PT Wana Kencana Sejati dan PT Wana Kencana Sejati Unit II, dan menghukum Pemohon Peninjauan Kembali untuk membayar biaya perkara dalam pemeriksaan Peninjauan Kembali ini sebesar Rp. 2.500.000,00. Hal ini berarti IUP yang diberikan oleh Bupati kepada PT Kemakmuran Pertiwi Tambang dan PT Kemakmuran Inti Utama Tambang tetap berlaku sah.

Pada tanggal 12 April 2016, Gubernur membatalkan putusan Bupati melalui Keputusan Gubernur Maluku Utara Nomor 235/KPTS/MU/2016 tertanggal 12 April 2016 tentang Pembatalan Keputusan Bupati Halmahera timur 
Nomor

$188.45 / 122 / 540.11 / 2007$

tentang

Pemberian

Kuasa

Pertambangan

Eksploitasi

PT

Kemakmuran Pertiwi Tambang terletak di Kabupaten Halmahera Timur seluas $1.000 \mathrm{Ha}$ dan atau telah disesuaikan menjadi Izin Usaha Pertambangan (IUP) Operasi Produksi, dimana seharusnya IUP tersebut berlaku sampai tahun 2027.5)

Keputusan Gubernur ini didasarkan pertimbangan pada putusan Peninjauan Kembali Nomor 90/PK/TUN/2009 tanggal 28 September 2009. Keputusan Gubernur ini sungguh tidak beralasan, karena dalam isi putusan PK tersebut tidak ada pernyataan untuk mencabut izin yang telah diterbitkan oleh Bupati.

Keputusan Gubernur ini merupakan Perbuatan Melawan Hukum karena tidak sesuai dengan putusan Peninjauan Kembali Nomor 90/PK/TUN/2009 tanggal 28 September 2009, dan telah merugikan PT Kemakmuran Pertiwi Tambang dan PT Kemakmuran Inti Utama Tambang selaku pemegang IUP. Keputusan Gubernur yang membatalkan IUP Eksploitasi PT Kemakmuran Pertiwi Tambang, tidak

5) Keputusan Gubernur Maluku Utara Nomor 235/KPTS/MU/2016 tertanggal 12 April 2016. sesuai dengan Ketentuan Pasal 46 Ayat (1) Undang-Undang Pertambangan, yang secara khusus telah memberikan perlindungan dan jaminan bagi setiap pemegang IUP Eksplorasi, untuk memperoleh IUP Operasi Produksi sebagai kelanjutan kegiatan usaha pertambangannya.

Keputusan Gubernur ini juga tidak sesuai dengan Fakta Mahkamah Agung No. 041/KMA/HK.01/III/2011 tanggal 17 Maret 2011, yang menyatakan "Sesuai dengan Keputusan Menteri Energi dan Sumber Daya Mineral No.1603.K/40/MEM/2003,

menetapkan kuasa pertambangan eksplorasi dan kuasa pertambangan eksploitasi yang diajukan pada wilayah yang sama oleh beberapa perusahaan maka yang pertama-tama mendapatkan wilayah adalah yang paling dulu diterima dan memenuhi persyaratan mempunyai hak prioritas untuk diakui keabsahannya.

Keputusan Gubernur ini juga tidak sesuai dengan Ketentuan Pasal 12 Ayat (1) huruf b Peraturan Menteri Energi dan Sumber Daya Mineral Nomor 43 tahun 2015 tentang Tata Cara Evaluasi Penerbitan Izin Usaha Pertambangan Mineral dan Batubara (selanjutnya 
disebut Permen ESDM Nomor 43 Terhadap Keputusan Gubernur, pihak Tahun 2015) menyatakan "Dalam hal PT Kemakmuran Pertiwi Tambang berdasarkan hasil evaluasi yang mengajukan gugatan di Pengadilan dilakukan oleh Direktur Jenderal atau Tata Usaha Negara Ambon. Adapun Gubernur terdapat tumpang tindih Pertimbangan Hakim dalam Putusan WIUP dengan WIUP lain yang sama Pengadilan Tata Usaha Negara Ambon komoditas, Direktur Jenderal atau dan Putusan Pengadilan Tinggi Tata Gubernur melakukan penerapan sistem Usaha Negara Makasar adalah terdapat permohonan pertama pencadangan tumpang tindih seluruh wilayah wilayah yang telah memenuhi pertambangan antara PT Kemakmuran persyaratan, mendapat prioritas Pertiwi Tambangan dengan PT Wana pertama untuk diberikan IUP (first come first served), apabila seluruh WIUP tumpang tindih.

Kencana Mineral dan IUP yang berlaku secara sah adalah IUP yang Pertama diterbitkan. Namun dalam Keputusan Gubernur ini dianggap Putusannya, baik Putusan Hakim melanggar asas kepatutan dalam hirarki, yaitu asas "lex superior derogat lex inferior," yang artinya peraturan yang lebih rendah tidak boleh bertentangan dengan peraturan perundang-undangan yang berada pada jenjang lebih tinggi. Keputusan Gubernur ini juga Pengadilan Tata Usaha Negara Ambon maupun Putusan Hakim Pengadilan Tinggi Tata Usaha Negara Makasar sama sama tidak teliti bahwa PT Kemakmuran Pertiwi Tambang telah mendapatkan IUP terlebih dahulu, seharusnya gugatan PT Kemakmuran melanggar Asas-Asas Umum Pemerintahan yang Baik (algemene beginselen van behoorlijk bestuur), terutama Asas Kepastian Hukum, Asas Tertib Penyelenggaraan Negara, Asas Keterbukaan, Asas Ketidakberpihakan, Asas Kecermatan, Asas Tidak Menyalahgunakan Kewenangan. Pertiwi Tambang dapat diterima.

PT Kemakmuran Pertiwi Tambang mengajukan Peninjauan Kembali ke Mahkamah Agung terhadap Putusan Hakim diatas. Namun dalam pertimbangan hukumnya, hakim Mahkamah Agung hanya menguatkan Putusan Pengadilan Tinggi Tata Usaha 
Negara Makasar. Hakim tidak memeriksa kembali substansi gugatan. Berdasarkan pada uraian tersebut diatas, maka diangkatlah judul penelitian ini adalah "Penerapan Prinsip First Come First Served Dalam Penyelesaian Tumpang Tindih Wilayah Izin Usaha Pertambangan”.

\section{B. Perumusan Masalah}

Berdasarkan uraian latar belakang di atas, maka permasalahan yang akan dibahas dalam penelitian ini adalah:

1. Bagaimana kepastian hukum pemberian izin usaha pertambangan operasi produksi bagi pemegang izin usaha pertambangan eksplorasi pada wilayah IUP yang tumpag tindih menurut Undang-Undang Pertambangan dan peraturan perundang-undangan lainnya?

2. Apakah Keputusan Gubernur Maluku Utara Nomor 235/KPTS/MU/2016 tertanggal 12 April 2016 tentang Pembatalan Keputusan Bupati Halmahera timur Nomor $\quad 188.45 / 122 / 540.11 / 2007$ tentang Pemberian Kuasa Pertambangan Eksploitasi PT
Kemakmuran Pertiwi Tambang terletak di Kabupaten Halmahera Timur seluas $1.000 \mathrm{Ha}$ telah sesuai dengan peraturan perundangundangan?

\section{Metode Penelitian}

1. Jenis penelitian

Jenis penelitian yang digunakan dalam penelitian ini adalah penelitian hukum normatif atau biasa disebut dengan penelitian untuk keperluan akademis. $^{6)}$

2. Sifat Penelitian

Penelitian yang dikaji merupakan penelitian yang bersifat preskriptif, dengan maksud untuk memberikan argumentasi atas hasil penelitian yang telah dilakukan. Penelitian yang bersifat preskriptif ini dipilih dan digunakan untuk mencari solusi dan mencari jawaban tentang apa yang seharusnya dari suatu permasalahan.

Jenis dan Teknik Pengumpulan Bahan Hukum

\footnotetext{
6) Peter Mahmud Marzuki, Penelitian Hukum (Jakarta: Kencana Prenada Media Group, 2016), 59.
} 
Dalam metode penelitian normatif menurut Peter Mahmud, sumber penelitian hukum dikategorikan menjadi sumber penelitian yang berupa bahan hukum primer yang merupakan pertaturan perundang-undangan, bahan hukum sekunder yang merupakan buku atau literatur hukum dan non hukum yang merupakan KBBI.7)

Teknik pengumpulan bahan hukum yang digunakan adalah studi dokumen atau studi kepustakaan. Studi dokumen dilakukan melalui bahan hukum tertulis dengan menggunakan content analysis yang merupakan suatu alat pengumpulan bahan hukum.8) Teknik ini digunakan untuk mendapatkan landasan teori dengan mengkaji dan mempelajari buku-buku, peraturan perundang-undangan, dokumen, laporan, arsip dan hasil penelitian lainnya baik cetak maupun elektronik yang berhubungan dengan kekuatan mengikat suatu peraturan

\footnotetext{
7 ) Ibid., hal. 181 .

${ }^{8}$ ) Ibid., hal. 181.
}

perundang-undangan. Selain itu, juga digunakan teknik wawancara dengan narasumber (ahli hukum) sebagai upaya mendapatkan pendapat hukum tentang objek yang diteliti.

3. Pendekatan Penelitian

Metode pendekatan yang digunakan dalam penelitian ini adalah pendekatan perundangundangan atau statute approach yang memahami hierarki dan asas-asas dalam peraturan perundang-undangan. Metode ini dipilih karena Penulis menganggap bahwa pendekatan perundang-undangan adalah yang paling tepat untuk menjawab permasalahan atau isu hukum dalam penulisan ini, yang mengkaji tentang penerapan prinsip first come first served dalam penyelesaian tumpang tindih wilayah izin usaha pertambangan.

4. Teknik Analisis Bahan Hukum

5. Dalam penelitian ini akan digunakan analisa data dengan teknik analisis normatif kualitatif, karena dalam teknik 
analisis normatif kualitatif akan dilakukan penarikan kesimpulan dengan logika deduktif. Peter Mahmud Marzuki mengutib pendapat Philipus M. Hadjon tentang metode deduksi yang merupakan silogisme dalam ajaran Aristoteles. Penggunaan metode ini berawal dari pengajuan premis mayor yang diikuti premis minor, kemudian diambil suatu kesimpulan atau conclusion. Silogisme hukum tidak sesederhana silogisme tradisional. 9 ) Penelitian ini menggunakan teknik logika deduktif yang menjelaskan suatu hal yang umum kemudian menariknya menjadi kesimpulan yang lebih khusus.10).

\section{PEMBAHASAN}

\section{A. Jaminan Kepastian Hukum Pemberian Izin Usaha} Pertambangan Operasi Produksi Yang Tumpang Tindih

9) Ibid., hal. 89.

10) Peter Mahmud Marzuki, Penelitian Hukum (Jakarta: Kencana, 2008), 47.
Kepastian hukum berarti adanya aturan yang bersifat umum yang mengatur perbuatan apa yang boleh atau tidak boleh dilakukan setiap individu dan kepastian hukum juga merupakan pelindung setiap individu dari kesewenangan pemerintah yang mengatur apa saja yang boleh atau tidak boleh dilakukan negara terhadap individu. $^{11)}$

Izin menjadi instrumen pemenuhan kepastian hukum bagi setiap orang yang melakukan kegiatan usaha pertambangan. Izin untuk melaksanakan usaha pertambangan terdiri dari dua jenis yaitu;

a. IUP Ekplorasi, ijin untuk melakukan tahapan kegiatan penyelidikan umum, eksplorasi, dan studi kelayakan;

b. IUP Operasi Produksi, diberikan setelah pelaksanaan IUP Eksplorasi, dan bertujuan untuk melakukan tahapan kegiatan operasi produksi.

\footnotetext{
11) Riduan Syahrani, Rangkuman Intisari Ilmu Hukum (Bandung: Citra Aditya Bakti, 1999), 23.
} 
Jangka waktu berlakunya izin usaha pertambangan dimaknakan sebagai lamanya masa waktu berlakunya izin usaha pertambangan yang diterima oleh pemegang IUP dan setiap IUP memiliki jangka waktu yang berbeda tergantung pada jenis pertambangannya. $^{12)}$

Menurut Penulis, jangka waktu berlakunya IUP Operasi Produksi milik PT KPT berlaku sampai 2027, sebab IUP Eksplorasi yang didapat tahun 2005, telah ditingkatkan menjadi IUP Operasi Produksi pada tahun 2007, berdasarkan Surat Keputusan Bupati Halmahera Timur Nomor 188.45/122/540.11/2007.

IUP yang berakhir karena dikembalikan adalah IUP yang dikembalikan secara tertulis kepada pejabat yang berwenang seperti menteri atau gubernur sesuai dengan kewenangannya. Pemegang IUP harus mengemukakan alasan yang jelas seperti tidak ditemukannya

12) Salim HS, Pengantar Hukum Sumber Daya Alam (Depok: Rajawali Pers, 2018), 171. prospek secara teknis, ekonomis, atau lingkungan. Pengembalian IUP dinyatakan sah, apabila:
a. Menteri atau Gubernur menyetujuinya;

b. Kewajibannya telah terpenuhi. ${ }^{13)}$

IUP yang berakhir karena dicabut adalah IUP yang dinyatakan ditarik kembali atau dinyatakan tidak berlaku lagi atau yang dibatalkan oleh pejabat yang berwenang seperti menteri atau gubernur sesuai dengan kewenangannya. Menurut Pasal 119 Undang-Undang Pertambangan, ada tiga alasan dalam pencabut IUP meliputi:

a. Adanya kelalaian dalam memenuhi kewajiban yang ditetapkan IUP;

b. Adanya tindakan pidana yang dilakukan oleh pemegang IUP; atau

c. Adanya pernyataan pailit terhadap pemegang IUP. ${ }^{14)}$

Menurut Penulis, PT KPT tidak pernah melakukan pelanggaran terhadap Pasal ini,

\footnotetext{
13) Ibid., hal. 175

14) Ibid., hal. 176.
} 
sebab PT KPT selalu memenuhi kewajibannya sebagaimana telah ditetapkan dalam IUP, tidak pernah dituntut melakukan tindak pidana di Pengadilan Negeri dan tidak pernah diajukan pailit di Pengadilan Niaga. Oleh karena itu, PT KPT tidak memenuhi syarat pencabutan yang diatur dalam Undang-Undang Pertambangan.

Ketentuan Pasal 46 Ayat 1 Undang-Undang Pertambangan yang secara khusus telah memberikan jaminan atau perlindungan bagi setiap pemegang IUP Eksplorasi untuk memperoleh IUP Operasi Produksi sebagai kelanjutan kegiatan usaha pertambangannya. Namun dalam prakteknya, tidak semua pemegang IUP Eksporasi berhak mendapatkan IUP Operasi Produksi, seperti yang terjadi pada PT KPT yang telah memiliki IUP sejak tahun 2005. IUP PT KPT dicabut karena telah tejadi tumpang tindih padahal pihak lawan PT WKM baru memiliki IUP Eksplorasi pada tahun 2007.
Terhadap wilayah yang tumpang tindih, Direktur Jenderal ESDM melalui surat No. 516/30/DJB/2011 tertanggal 16 Februari 2011, menyatakan "Sesuai Keputusan Menteri ESDM No. 1603.K/40/MEM/2003 yang menetapkan Kuasa Pertambangan eksplorasi dan Kuasa Pertambangan eksploitasi yang diajukan pada wilayah yang sama oleh beberapa perusahaan maka yang pertama-tama mendapatkan wilayah adalah yang paling dulu diterima dan memenuhi persyaratan mempunyai hak prioritas untuk diakui keabsahannya.

Selain itu, dalam Pasal 12 ayat (1) huruf b Peraturan Menteri Energi dan Sumber Daya Mineral Nomor 43 tahun 2015 tentang Tata Cara Evaluasi Penerbitan Izin Usaha Pertambangan Mineral dan Batubara juga menyatakan "Dalam hal berdasarkan hasil evaluasi yang dilakukan oleh Direktur Jenderal atau Gubernur terdapat tumpang tindih WIUP dengan WIUP lain yang sama komoditas, Direktur Jenderal atau Gubernur 
melakukan : "penerapan sistem permohonan pertama pencadangan wilayah yang telah memenuhi persyaratan, mendapat prioritas pertama untuk diberikan IUP first come first served), apabila seluruh WIUP tumpang tindih”. Menurut pendapat M. Khoiriza Nasution bahwa dalam satu wilayah pertambangan kemungkinan terdapat dua ijin usaha, tetapi ijin ini harus berbeda komoditasnya, sebagai contohnya pada wilayah yang sama terdapat emas dan batubara, maka di wilayah itu terdapat 2 (dua) ijin yang berbeda. Namun untuk komoditas yang sama tidak diperkenankan adanya 2 (dua) ijin. Untuk menyelesaikan sengketa tumpang tindih terhadap 2 ijin yang sama dapat dilakukan melalui beberapa tahap yaitu;

a. Penciutan, pemerintah sebagai perantara dalam negosiasi mengundang kedua belah pihak yang bersengketa, apabila terjadi kata sepakat untuk IUP yang tumpang tindih, maka akan dilakukan penciutan terhadap IUP yang ada. b. Pencabutan, dilakukan berdasarkan pada keputusan Pengadilan Tata Usaha Negara yang telah inkrah. Artinya para pihak yang bersengketa mengajukan gugatan ke Pengadilan Tata Usaha Negara terhadap IUP yang tumpang tindih. ${ }^{15)}$

Menurut penulis, selain menggunakan kedua metode diatas, ada baiknya jika menggunakan peraturan perundang-undangan, yaitu Pasal 12 Permen ESDM Nomor 43 Tahun 2015. IUP PT KPT seharusnya tidak dapat dicabut oleh Gubernur Maluku Utara sebab IUP PT KPT telah diterbitkan pada tahun 2005, sedangkan pihak lawan baru diterbitkan pada tahun 2007. Selain itu, PT KPT juga tidak melakukan pelanggaran dalam Pasal 119 Undang-Undang Pertambangan.

Menurut Bisman Bakhtiar, selaku Direktur Eksekutif Pusat

15) Peneliti, Wawancara, dengan M. Khoiriza Nasution analisa hukum Kepala Biro Hukum sekretariat Jenderal Kementerian Energi dan Sumber Daya Mineral, (Jakarta: Biro Hukum Sekretariat Jenderal Kementerian ESDM, Jalan Merdeka Selatan No. 18, 10110, 20 Mei 2019). 
Studi Hukum Energi dan Pertambangan, menyatakan bahwa seringnya terjadi tumpang tindih IUP pada areal yang sama, menyebabkan Menteri ESDM menerbitkan Peraturan Menteri Energi dan Sumber Daya Mineral Nomor 43 Tahun 2015 tentang Tata Cara Evaluasi Penerbitan Izin Usaha Pertambangan Mineral dan Batubara, yang isinya mengatur tentang Sertifikat Clean and Clear (selanjutnya disingkat $\mathrm{CnC}$ ) yaitu terhadap IUP yang telah diterbitkan oleh Bupati atau Gubernur harus mendapatkan sertifikat $\mathrm{CnC}$ yang diterbitkan oleh Dirjen Minerba Kementerian ESDM. $^{16)}$

Penulis sependapat dengan Bisman Bakhtiar, bahwa IUP yang diterbitkan oleh Bupati maupun Gubernur harus mendapatkan sertifikat $\mathrm{CnC}$ yang diterbitkan oleh Dirjen Minerba Kementerian ESDM karena dengan adanya Sertifikat ini maka tidak akan

16 ) Peneliti, Wawancara, dengan Bisman Bakhtiar Direktur Eksekutif Pusat Studi Hukum Energi dan Pertambangan, (Jakarta: Pusat Studi Hukum Energi dan Pertambangan, Gedung Graha Samali Lt. 2 Ruang 2003B Jalan Samali No. 31 B, 12740, 25 April 2019). terjadinya tumpang tindih. Berkaitan dengan hal tersebut Ketentuan Pasal 12 ayat (1) huruf b Peraturan Menteri Energi dan Sumber Daya Mineral Nomor 43 tahun 2015 tentang Tata Cara Evaluasi Penerbitan Izin Usaha Pertambangan Mineral dan Batubara (selanjutnya disebut Permen ESDM No. 43 tahun 2015) menyatakan "Dalam hal berdasarkan hasil evaluasi yang dilakukan oleh Direktur Jenderal atau Gubernur terdapat tumpang tindih WIUP dengan WIUP lain yang sama komoditas, Direktur Jenderal atau Gubernur melakukan: penerapan sistem permohonan pertama pencadangan wilayah yang telah memenuhi persyaratan, mendapat prioritas pertama untuk diberikan IUP (first come first served), apabila seluruh WIUP tumpang tindih.

Oleh karena penataan IUP yang bermasalah telah selesi dilakukan, maka peraturan tentang $\mathrm{CnC}$ dicabut melalui Peraturan Menteri Energi Dan Sumber Daya Mineral Nomor 11 Tahun 2018 tentang Tata Cara Pemberian 
Wilayah, Perizinan, dan Pelaporan pada

Kegiatan

Usaha

Pertambangan Mineral dan

Batubara. Hal ini disampaikan oleh

Direktur Jenderal Mineral dan

Batubara Kementerian ESDM

Bambang Gatot Aryono bahwa

$\mathrm{CnC}$ sudah tidak diperlukan lagi.

Bagi perusahaan yang mengajukan gugatan karena dianggap non $\mathrm{CnC}$, akan tetap dibekukan pelayanannya sampai ada keputusan Pengadilan atau ombudsman yang menyatakan perusahaan bersangkutan tidak bermasalah.

Bisman Bakhtiar berpendapat bahwa berdasarkan UndangUndang Kehakiman, hakim merupakan wakil Tuhan dalam menyelesaikan perkara. Hakim dalam memutuskan perkara akan menimbang rasa keadilan dan rasa kepastian hukum. Hakim bebas dan tidak terikat memutuskan perkara, sepanjang tidak ada indikasi penyimpangan seperti korupsi, suap, dan macam-macam. Namun kadang kala keputusan hakim dalam suatu perkara malah menyebabkan ketidakpastian hukum, karena hakim dalam menyelesaikan suatu perkara tidak didasarkan pada peraturan perundang-undangan yang berlaku. Hal ini didasarkan pada asas keyakinan hakim. ${ }^{17)}$

M. Khoiriza Nasution menyatakan bahwa dalam Pengadilan Tata Usaha Negara biasanya hakim sebelum masuk pada substansi perkara, hakim terlebih dahulu melihat kewenangan Gubernur. Dalam hal pemberian atau pencabutan izin usaha yang diterbitkan Gubernur, kewenangnan Gubernur berdasarkan pada kewenangan atributif yang diberikan oleh undang-undang. Setelah Hakim mengetahui bahwa gugatan telah sesuai dengan kewenangan Gubernur, kemudian Hakim melakukan pengecekkan apakah dalam memberikan atau membatalkan IUP Gubernur telah sesuai pada prosedur yang ada. Setelah itu Hakim baru

17) Peneliti, Wawancara, dengan Bisman Bakhtiar Direktur Eksekutif Pusat Studi Hukum Energi dan Pertambangan, (Jakarta: Pusat Studi Hukum Energi dan Pertambangan, Gedung Graha Samali Lt. 2 Ruang 2003B Jalan Samali No. 31 B, 12740, 25 April 2019). 
menganalisis Substansi perkara. Hakim dalam menyelesaikan perkara tidak hanya menggunakan asas-asas dalam Undang-Undang Nomor 51 Tahun 2009 tentang Perubahan Kedua atas UndangUndang Nomor 5 tahun 1986 tentang Peradilan Tata Usaha Negara (selanjutnya disebut UU TUN), Undang-Undang Nomor 30 Tahun 2014 tentang Administrasi Pemerintahan (selanjutnya disebut UUAP), Undang-Undang Nomor 28 Tahun 1999 tentang Penyelenggara Negara Yang Bersih Dan Bebas Dari Korupsi, Kolusi, dan Nepotisme (selanjutnya disebut UU KKN), tetapi hakim dapat menggunakan asas lainnya, contohnya hakim dapat menggunakan asas kepatutan, asas penghargaan yang layak. $^{18)}$

Penulis sependapat dengan pendapat Bisman Bakhiar dan M. Khoiriza Nasution, yaitu hakim dalam membuat suatu keputusan

18) Peneliti, Wawancara, dengan M. Khoiriza Nasution analisa hukum Kepala Biro Hukum sekretariat Jenderal Kementerian Energi dan Sumber Daya Mineral, (Jakarta: Biro Hukum Sekretariat Jenderal Kementerian ESDM, Jalan Merdeka Selatan No. 18, 10110, 20 Mei 2019). mempunyai kewenangan secara penuh. Namun, dalam mengambil suatu keputusan hakim harus menjunjung pada norma kehakiman (Undang-Undang Nomor 48 Tahun 2009 tentang Kekuasaan Kehakiman), hakim harus tunduk dan taat pada perarturan perundang-undangan.

Dalam kasus ini majelis hakim yang mengadili perkara aquo tidak menganalisis substansi perkara, ternyata pada pertimbangan hakim yang tidak memperhatikan Undang-Undang Pertambangan maupun peraturan pelaksanaannya. Keputusan hakim ini berlawanan dengan Undang-Undang Pertambangan. Dengan adanya suatu putusan yang bertentangan dengan Undang-Undang Pertambangan dapat disimpulkan tidak ada kepastian hukum bagi pemegang IUP Eksporasi untuk mendapatkan IUP Operasi Produksi. Hakim tidak memperhatikan syarat pencabutan IUP Operasi Produksi yang telah diatur dalam Undang-Undang Pertambangan. Berkaitan dengan hal tersebut, jika ditinjau dalam 
pasal 119 Undang-Undang

Pertambangan, IUP PT KPT ini

seharusnya tidak dibatalkan karena

PT KPT ini tidak pernah melanggar Undang-Undang tersebut.

Pertimbangan hakim dalam Putusan Pengadilan Tata Usaha Negara adalah karena terdapat tumpang tindih seluruh wilayah pertambangan antara KP Eksploitasi Penggugat dengan IUP Operasi Produksi Tergugat II, Intervensi, dan masing-masing dengan komoditas yang sama, maka untuk memberikan kepastian hukum bagi pelaku usaha pertambangan di wilayah provinsi Maluku Utara Tergugat selaku pembina dan pengawas Usaha Pertambangan harus mencabut salah satunya.

Penulis berpendapat bahwa dengan adanya Undang-Undang Pertambangan yang mengatur mengenai jaminan pemberian IUP dan Permen ESDM No 43 tahun 2015 mengatur mengenai tumpang tindih, maka menurut penulis terhadap kasus tersebut tidak mempunyai kepastian hukum karena sudah jelas diatur dalam Permen ESDM No 43 tahun 2015 bahwa apabila terjadi tumpang tindih adalah yang pertama memenuhi persyaratan. Perlu diingat bahwa Pihak KPT yang terlebih dahulu memeiliki IUP Operasi Produksi, sehingga Pihak KPT harusnya mendapat prioritas pertama.

Kewenangan kehakiman yang mandiri dalam membuat suatu keputusan yang tidak dikuti dengan peraturan perundanganundangan dapat membuat ketidakpastian bagi pelaku usaha pertambangan. Putusan hakim dalam Putusan Nomor 203 PK/TUN/2017 telah bertentangan dengan peraturan perundanganundangan khususnya UndangUndang Pertambangan. Dengan demikian, kepastian hukum tidak terwujud bagi pemegang IUP Operasi Produksi walaupun Undang-Undang Pertambangan telah menjamin hal ini dalam Pasal 46 Undang-Undang Pertambangan. 
B. Kesesuaian

Keputusan

Gubernur Maluku Utara Nomor

235/KPTS/MU/2016

Tentang

Pembatalan Keputusan Bupati

Halmahera Timur Nomor

188.45/122/540.11/2007 Tentang

Pemberian

Kuasa

Pertambangan Eksploitasi PT

Kemakmuran Pertiwi Tambang

Terletak di Kabupaten

Halmahera Timur seluas $\mathbf{1 . 0 0 0}$

Ha dengan Peraturan

Perundang-Undangan

Tata cara pencabutan IUP

telah diatur dalam Pasal 119

Undang-Undang Pertambangan

yang menyatakan IUP atau IUPK

dapat dicabut oleh Menteri,

Gubernur, atau Bupati/walikota

sesuai dengan kewenangannya

dengan persyaratan; Pemegang

IUP atau IUPK tidak memenuhi

kewajiban, melakukan tindak pidana sebagaimana dimaksud dalam Undang-Undang ini; atau dinyatakan pailit.

Berdasarkan syarat tersebut di atas, pencabutkan atau pembatalan yang dilakukan oleh Gubernur Maluku Utara tidak didasarkan pada Pasal 19 Undang-Undang
Pertambangan, sebab PT KPT telah memenuhi kewajibannya sebagaimana telah ditetapkan oleh IUP dan peraturan perundangundangan, PT KPT juga tidak pernah melakukan tindak pidana dan PT KPT tidak pernah dinyatakan pailit.

Pembagian urusan dibidang pertambangan mineral dan batubara diatur dalam lampiran Undang-Undang Nomor 23 Tahun 2014 tentang Pemerintah Daerah (selanjutnya disebut UU Perda). Urusan mineral dan batubara menjadi tugas dari pemerintah daerah provinsi. Pemerintah kabupaten/ kota tidak lagi mempunyai hak dalam penyelenggaraan urusan di bidang pertambangan dan batubara.

Asas-Asas

Umum

Pemerintahan yang Baik (selanjutnya disebut AAUPB) adalah prinsip yang digunakan sebagai acuan penggunaan wewenang bagi pejabat pemerintahan dalam mengeluarkan keputusan dan/atau tindakan dalam penyelenggaraan pemerintahan. Adapun AAUPB yang harus 
ditaati oleh gubernur diatur dalam Pasal 10 ayat (1) UUAP sebagai berikut:
a. Kepastian hukum
b. Kemanfaatan;
c. Ketidakberpihakan;
d. Kecermatan;
e. Tidak menyalahgunakan kewenangan;
f. Keterbukaan;
g. Kepentingan umum, dan
h. Pelayanan yang baik.

Larangan menyalahgunakan wewenang bagi badan/ pejabat pemerintah meliputi larangan melampaui wewenang, larangan mencampuradukkan wewenang, dan/ atau larangan bertindak sewenang-wenang yang diatur dalam Pasal 17 UUAP. Pengertian dari tindakan yang dilakukan badan dan/ atau pejabat pemerintahan dikategorikan sewenang-wenang yaitu tindakan dilakukan melampaui masa jabatan atau batas waktu berlakunya weweang, melampaui batas wilayah berlakunya wewenang dan bertentangan dengan ketentuan peraturan perundang-undangan. Hal ini tertera dalam Pasal 18 Ayat 1 UUAP. Sedangkan untuk tindakan yang dianggap sewenang- wenang adalah tindakan yang dilakukan tanpa dasar kewenangan dan bertentanngan dengan putusan pengadilan yang berkekuatan hukum tetap.

Pada tanggal 12 April 2016, Gubernur membatalkan putusan Bupati melalui Keputusan Gubernur Maluku Utara Nomor 235/KPTS/MU/2016 tertanggal 12 April 2016 tentang Pembatalan Keputusan Bupati Halmahera Timur Nomor $188.45 / 122 / 540.11 / 2007$ tentang Pemberian Kuasa Pertambangan Eksploitasi PT Kemakmuran Pertiwi Tambang terletak di Kabupaten Halmahera Timur seluas $1.000 \mathrm{Ha}$ dan atau telah disesuaikan menjadi Izin Usaha Pertambangan (IUP) Operasi Produksi, dimana seharusnya IUP tersebut berlaku sampai tahun 2027.

Bisman Bhaktiar menyatakan bahwa kewenangan gubernur dalam membatalkan surat keputusan yang dibuat oleh Bupati didasarkan pada Undang-Undang Nomor 9 Tahun 2015 tentang Perubahan Kedua Atas Undang- 
Undang Nomor 23 Tahun 2014 tentang Pemerintah Daerah. Dalam hal pembatalan IUP, gubernur berhak membatalkan IUP, apabila perusahaan pemegang IUP tidak memenuhi kewajiban, melakukan tindak pidana, dan dinyatakan pailit sesuai dengan Pasal 119 Undang-Undang Pertambangan. Gubernur dalam hal membatalkan IUP tidak boleh bertindak semena mena atau menyimpang dari kewenangannya. Hal ini sebagimana diatur dalam AAUPB.,"19)

Menurut Ryan Bakry bahwa sejak adanya perubahan UU Perda pada tahun 2015, Gubernur sebagai selain menjabat sebagai kepala daerah, juga merupakan wakil pemerintah pusat dalam hal menerbitkan ijin-ijin seperti IUP. Gubernur diberikan hak dan wewenang untuk membuat suatu keputusan (beschikking) seperti yang diatur lebih lanjut dalam Undang-Undang Nomor 30 Tahun

19 ) Peneliti, Wawancara, dengan Bisman Bakhtiar Direktur Eksekutif Pusat Studi Hukum Energi dan Pertambangan, (Jakarta: Pusat Studi Hukum Energi dan Pertambangan, Gedung Graha Samali Lt. 2 Ruang 2003B Jalan Samali No. 31 B, 12740, 25 April 2019).
2014 tentang Administrasi

Pemerintahan (selanjutnya disebut UUAP). Gubernur dalam hal kedudukannya sebagai pejabat administrasi negara harus tunduk pada UUAP. Dalam menerbitkan atau membatalkan suatu ijin, Gubernur harus memperhatikan apakah suatu PT sudah memenuhi persyaratan yang ada dalam peraturan perundangan-undangan untuk mendapatkan suatu ijin baik yang telah ada atau yang akan dibuat. Setiap keputusan dan/ atau tindakan harus ditetapkan dan/ atau dilakukan oleh badan dan/ atau pejabat pemerintahan yang berwenang, wajib berdasarkan peraturan perundang-undangan, dan AAUPB. Pejabat administrasi pemerintahan juga dilarang menyalahgunakan kewenangan dalam menetapkan dan/ atau melakukan keputusan dan/ atau tindakan sebagaimana diatur dalam Pasal 8 UUAP. Keputusan/ Tindakan Pejabat Administrasi negara harus berdasarkan peraturan perundang-undangan yang menjadi dasar kewenangan dan peraturan perundang- 
undangan yang menjadi dasar dalam menetapkan keputusan/ tindakan, sesuai Pasal 9 Ayat 2 Huruf a dan b UUAP. ${ }^{20)}$

Menurut M. Khoiriza Nasution bahwa sejak adanya UU Perda yang baru semua ijin-ijin hanya dapat diterbitkan oleh Gubernur selaku wakil pusat di daerah. Gubernur menerbitkan ijin terhadap wilayah tambang antar kabupaten dalam satu provinsi, sedangkan untuk wilayah tambang antar provinsi yang berhak mengeluarkan ijin adalah Kementerian ESDM. Kewenangan Gubernur Maluku Utara yang membatalkan surat keputusan Bupati Halmahera Timur merupakan kewenangan yang didapat dari UU Perda dan UUAP. Namun Gubernur tidak boleh bertindak sewenang-wenang atau melebihi kewenangannya dalam memberikan atau membatalkan ijin-ijin, Gubernur tetap harus memperhatikan peraturan

20) Peneliti, Wawancara, dengan Ryan Bakry Dosen Hukum Pemerintahan Negara Fakultas Hukum Universitas Tarumanagara, (Jakarta: Universitas Tarumanagara, Jalan Letjen S. Parman No. 1, 11440, 3 Mei 2019). perundang-undangan yang berlaku. Keputusan Gubernur pada dasarnya sah, karena telah sesuai kewenangannya. Namun secara substansi keputusan Gubernur Halmahera Timur yang dibuat berdasarkan putusan PK yang telah inkrah ini tidak sesuai dengan aturan perundang-undangan, sebab terdapat 2 putusan inkrah yang saling bertentangan. PT KPT menang terhadap gugatan yang diajukan PT WKM pada PK Nomor 63/PK/TUN/2010 namun disisi lain PT KPT kalah terhadap gugatan yang diajukannya pada PK Nomor 90/PK/TUN/2009.

Penulis sependapat dengan Bisman Bakhtiar, Ryan Bakry dan M. Khoiriza Nasution, dapat dipastikan bahwa Gubernur memang mempunyai hak untuk membatalkan IUP. Kewenangan ini didapat dari UUAP dan UU Perda, Gubernur dalam hal ini bertindak sebagai wakil pemerintah pusat di daerah. Namun dalam menerbitkan dan/ atau membatalkan suatu ijin, gubernur tidak boleh menyalahgunakan wewenangnya, 
mencampuradukkan wewenang dan bertindak sewenang-wenang. Apabila dikaitan dengan pembatalan yang dilakukan oleh Gubernur Maluku Utara terhadap IUP milik PT KPT, keputusan pembatalan ini tentu telah mencederai UUAP dan AAUPB. Hal ini dapat dijelaskan sebagai berikut;

a. Pembatalan IUP pada dasarnya harus memperhatikan UndangUndang Pertambangan, yaitu Pasal 119 Undang-Undang Pertambangan. PT KPT pada dasarnya tidak melanggar isi Pasal tersebut, karena PT KPT sampai saat ini tidak dinyatakan pailit, tidak melakukan tindakan pidana, dan tidak melanggar administrasi yang ditetapkan Undang-Undang

Pertambangan.

b. Pembatalan IUP yang dilakukan oleh gubernur, adalah berdasarkan Putusan PK No. 90/PK/TUN/2009 Dalam putusan PK tersebut, tidak ada amar putusan hakim yang menyatakan mencabut IUP milik PT KPT. Oleh karena gubernur telah melampaui batas wewenangan.

c. Pembatalan IUP yang dilakukan oleh Gubernur jelas telah melanggar isi dari AAUPB itu sendiri. Asas-asas ini termuat dalam Pasal 10 UUAP. Adapun uraian pelanggaran AAUPB yang dilakukan Gubernur Maluku Utara dalam membatalkan IUP PT KPT, yaitu;

1) Asas kepastian hukum, IUP milik PT KPT awalnya adalah IUP Eksplorasi yang terbit pada tanggal 27 april 2005. Dalam Pasal 46 Undang-Undang Pertambangan, terdapat jaminan pemberian IUP Operasi Produksi bagi pemegang IUP Eksplorasi. Dengan adanya pembatalan sepihak yang dilakukan oleh Gubernur Maluku Utara jelas telah 
menimbulkan

ketidakpastian hukum

karena keputusan yang

dibuat tidak berlandasan

pada ketentuan peraturan

perundang-undangan,

kepatutan, keajegan dan

keadilan.

2) Asas kemanfaatan

Pembatalan IUP yang

dilakukan Gubernur

Maluku Utara juga tidak memperhatikan asas

kemanfaatan. Gubernur

Maluku Utara tidak

memperhatikan

kepentingan individu,

masyarakat dan

pemerintah. Tindakan

Gubernur Maluku Utara

yang sewenang-wenang

ini tentu merugikan

berbagai pihak seperti

pengusaha pertambangan

menjadi ragu dalam

menginvestasikan

dananya di Indonesia.

Penurunan investasi akan

berpengaruh pendapatan

masyarakat dan

pendapatan negara.
3) Asas ketidakberpihakan

Pembatalan IUP milik PT

KPT juga mencederai asas ini, sebab PT KPT telah lebih dahulu memiliki IUP, sebelum PT WKM. Dalam Surat Keputusan Menteri Energi dan Sumber Daya Mineral Nomor 1603 K/40 MM/2003 tanggal 24 Desember 2003 Pasal 10 ayat (2) jo. Pasal 7 ayat (2) menyatakan bahwa dalam hal terjadi tumpang tindih dalam pencadangan wilayah antara Menteri atau Gubernur atau Bupati atau Walikota, pemohon yang lebih dahulu diterima dan telah memenuhi persyaratan mempunyai hak prioritas untuk diproses atau diakui keabsahannya. Hal ini berarti pemohon IUP yang pertama yang berhak mendapatkan IUP (fist come, first served).

4) Asas kecermatan 
Pembatalan IUP milik PT

KPT yang dilakukan oleh

Gubernur Maluku Utara

jelas melanggar asas

kecermatan, Gubernur

Maluku Utara tidak

memperhatikan informasi

dan dokumen yang

lengkap untuk

mendukung pembatalan

itu sebab PT KPT telah

terlebih dahulu memiliki

IUP Eksplorasi sejak

tahun 2005.

5) Asas

tidak

menyalahgunakan

wewenang

Pembatalan IUP milik PT

KPT yang dilakukan oleh

Gubernur Maluku Utara

jelas melanggar asas ini

sebab pembatalan yang

dilakukan oleh Gubernur

Maluku Utara tidak

berdasarkan Undang-

Undang dan tidak

berdasarkan putusan

pengadilan yang inkrah.

6) Asas keterbukaan

Pembatalan

yang

dilakukan Gubernur
Maluku Utara tidak

berdasarkan pada

informasi yang benar,

jujur, dan tidak

diskriminatif. Gubernur

Maluku Utara tidak

memperhatikan syarat-

syarat pembatalan IUP

berdasarkan Undang-

Undang Pertambangan.

7) Asas kepentingan umum

Dengan adanya

pembatalan yang

dilakukan oleh Gubernur

Maluku Utara telah

merugikan kepentingan

umum berbagai pihak

yaitu pengusaha

pertambangan yang telah

menanamkan investasi

semasa mendapatkan IUP

eksplorasi, masyarakat

yang berada di daerah

sekitar pertambangan

menjadi tidak bisa bekerja

dan pendapatan

keuntungan bagi

pemerintah atas usaha

pertambangan tersebut.

8) Asas pelayanan yang baik 
Gubernur Maluku Utara

dalam hal pembatalan

IUP milik PT KPT telah

tidak sesuai dengan prosedur berdasarkan standar pelayanan, dan ketentuan peraturan perundang-undangan.

\section{PENUTUP}

\section{A. Kesimpulan}

1. Kepastian hukum pemberian Izin Usaha Pertambangan Operasi Produksi bagi pemegang Izin Usaha Pertambangan Eksplorasi pada wilayah IUP yang tumpang tindih tidak terlaksana, sebagaimana telah diatur dalam Undang-Undang Pertambangan dan peraturan perundang-undangan lainnya. Hal ini terbukti dari telah dilanggarnya pasal-pasal sebagai berikut:

a. Pasal 46 Undang-Undang Pertambangan, yang mana jelas-jelas memberikan jaminan atau kepastian hukum kepada pemegang IUP Eksplorasi untuk mendapatkan IUP Operasi Produksi;

b. Keputusan

Menteri ESDM No. 1603.K/40/MEM/2003, yang menetapkan perusahaan yang pertamatama mendapatkan prioritas untuk diakui keabsahannya dalam mendapatkan wilayah adalah perusahaan yang pertama kali diterima dan memenuhi persyaratan yang ditetapkan undangundang;

c. Keputusan Direktur Jenderal ESDM Nomor 516/30/DJB/2011

tertanggal $16 \quad$ Februari 2011 yang menyatakan kuasa pertambangan ekslorasi dan kuasa pertambangan eksploitasi yang diajukan pada wilayah yang sama oleh beberapa perusahaan, maka yang pertama-tama mendapatkan wilayah adalah yang paling dulu diterima dan memenuhi 
persyaratan mempunyai

hak prioritas untuk diakui

keabsahannya;

d. Pasal 12 Ayat (1) huruf b Permen ESDM Nomor 43

Tahun 2015, yang menyatakan bahwa dalam hal terjadi tumpang tindih wilayah ijin usaha pertambangan dengan wilayah ijin usaha pertambangan lain yang sama komoditasnya, maka Direktur Jendral atau Gubernur akan menerapkan sistem permohonan pertama pencadangan wilayah yang telah memenuhi persyaratan, mendapat prioritas pertama untuk diberikan IUP (first come first served).

2. Keputusan Gubernur Maluku Utara Nomor

235/KPTS/MU/2016

tertanggal 12 April 2016 tentang Pembatalan

Keputusan Bupati Halmahera timur Nomor $188.45 / 122 / 540.11 / 2007$ tentang Pemberian Kuasa Pertambangan Eksploitasi PT Kemakmuran Pertiwi

Tambang terletak di Kabupaten Halmahera Timur seluas $1.000 \mathrm{Ha}$ tidak sesuai dengan peraturan perundangundangan, hal ini dikarenakan bahwa keputusan gubernur di atas telah melanggar pasalpasal sebagai berikut:

a. Pasal 119 UndangUndang Pertambangan, dalam pasal ini telah diatur bahwa pencabutan IUP hanya dapat dilakukan apabila pemegang IUP pailit, melakukan tindak pidana dan/ atau tidak memenuhi kewajiban yang tetapkan dalam IUP;

b. Pasal 58 UU Perda, dalam pasal ini gubernur dalam menjalankan

pemerintahkan harus memenuhi asas-asas penyelanggaraan pemerintahan daerah;

c. Pasal 10 UUAP, yang berisi bahwa Gubernur 
dalam menjalankan

pemerintahan harus

memenuhi AAUPB;

d. Pasal 17 UUAP, yang

berisi larangan bagi

Gubernur untuk

melakukan

penyalahgunaan

wewenangnya,

mencampuradukkan

wewenang dan bertindak

sewenang-wenang.

B. Saran

1. Demi menjaga adanya kepastian hukum bagi pemegang IUP sebagaimana telah diatur dalam Pasal 46 Undang-Undang

Pertambangan, maka menurut penulis sebaiknya:

a. Gubernur sebagai wakil dari pemerintah pusat di daerah seharusnya dalam membuatkan keputusan atau tindakan tata usaha negara berdasarkan pada peraturan perundangundangan yang berlaku, menaati UUAP dan Asasasas Umum Pemerintahan yang Baik. Untuk itu, perlu ada pendidikan khusus bagi Gubernur;

b. Sedangkan hakim yang merupakan wakil Tuhan dalam menyelesaikan suatu perkara harus berdasarkan nilai-nilai keadilan. Mereka harus mengerti semua produk perundang-undangan yang berlaku. Keputusan hakim yang tidak didasarkan pada peraturan perundangundangan tentu akan mencederai nilai-nilai keadilan, sehingga negara kita dianggap bukan negara hukum.

c. Selain itu perlu adanya revisi Undang-Undang Pertambangan khususnya tentang pemberian dan pencabutan IUP. Revisi ini bertujuan memberikan jaminan kepastian hukum bagi pemegang IUP. Dengan adanya kepastian hukum semua pihak akan merasakan nilai-nilai keadilan. 
2. Agar tidak terjadi penyalagunaan wewenang yang dilakukan oleh kepala daerah dalam menjalankan pemerintahan, maka menurut Penulis ada baiknya bila pemerintah pusat memberikan sanksi yang keras terhadap pelanggaran yang dilakukan kepala daerah.

\section{DAFTAR PUSTAKA}

\section{A. Buku}

Marzuki, Peter Mahmud. Penelitian Hukum. Jakarta: Kencana Prenada Media Group, 2016.

Penelitian Hukum. Cetakan ke-4. Jakarta: Kencana, 2008.

Redi, Ahmad. Hukum Pertambangan. Jakarta: Gramata Publishing, 2014.

Saleng, Abrar. Hukum Pertambangan. Yogyakarta: UII Press, 2004.

Salim HS, Hukum Pertambangan Indonesia. Jakarta: Rajawali Pers, 2012.

Syahrani, Riduan. Rangkuman Intisari Ilmu Hukum. Bandung: Penerbit Citra Aditya Bakti, 1999.

Yamin, Muhammad dan Abdul Rahim Lubis. Hukum Pendaftaran Tanah.

Bandung: Mandar Maju, 2008.

\section{B. Artikel Jurnal Online}

Anonim. "Indonesia Overview". www.resourceqovernance.o rg. Diakses tanggal 28 Januari 2019, 15.48 WIB.

\section{Perundang-undangan}

Indonesia. Undang-Undang Nomor 5 Tahun $1960 \quad$ tentang Peraturan Dasar PokokPokok Agraria (Lembaran Negara Republik Indonesia Tahun 1960 Nomor 22, Tambahan Lembaran Negara Republik Indonesia Nomor 2043).

Undang-Undang Nomor 4 Tahun 2009 tentang Pertambangan Mineral dan Batubara (Lembaran Negara Republik Indonesia Tahun 2009 Nomor 104, Tambahan Lembaran Negara Republik Indonesia Nomor 4959).

Undang-Undang Nomor 23 Tahun 2014 tentang Pemerintahan Daerah (Lembaran Negara Republik Indonesia tahun 2014 Nomor 244, Tambahan Lembaran Negara Republik Indonesia Nomor 5587).

. Undang-Undang Nomor 30 Tahun 2014 tentang Administrasi Pemerintahan (Lembaran Negara Republik Indonesia tahun 2014 Nomor 292, Tambahan Lembaran Negara Republik Indonesia Nomor 5601).

Undang-Undang Nomor 9 Tahun 2015 tentang 
Volume 17, No. 2, Oktober 2019

Perubahan Kedua atas Undang-Undang Nomor 23

Tahun 2014 tentang

Pemerintahan Daerah

(Lembaran Negara Republik

Indonesia tahun 2015

Nomor 58, Tambahan

Lembaran Negara Republik

Indonesia Nomor 5679).

Peraturan Menteri Energi dan Sumber Daya Mineral Nomor 43 Tahun 2015 tentang Tata Cara Evaluasi

Penerbitan Izin Usaha Pertambangan Mineral dan Batubara (Lembaran Negara Republik Indonesia Tahun 2015 Nomor 2014).

Peraturan Menteri Energi dan Sumber Daya Mineral Nomor 11 Tahun 2018 tentang Tata Cara Pemberian Wilayah, Perizinan dan Pelaporan pada Kegiatan Usaha Pertambangan Mineral dan Batubara (Lembaran Negara Republik Indonesia Tahun 2018 Nomor 295).

\section{Putusan Pengadilan}

Indonesia. Putusan Peninjauan Kembali Pengadilan Tata Usaha Negara Nomor 203 PK/TUN/2017. 